\title{
PENGARUH PENGETAHUAN TENTANG PASAR MODAL SYARIAH TERHADAP MINAT INVESTASI SAHAM DI PASAR MODAL SYARIAH
}

\author{
Malkan Malkan'1, Indra Kurniawan², Nurdin Nurdin ${ }^{3}$, Noval Noval ${ }^{4}$
}

1 Jurusan Perbankan, Fakultas Ekonomi dan Bisnis Islam, IAIN Palu,

2 Jurusan Perbankan, Fakultas Ekonomi dan Bisnis Islam, IAIN Palu,

3 Jurusan Perbankan, Fakultas Ekonomi dan Bisnis Islam, IAIN Palu,

4 Jurusan Perbankan, Fakultas Ekonomi dan Bisnis Islam, IAIN Palu,

ABSTRAK

Tujuan penelitian ini adalah untuk mengetahui pengaruh pengetahuan tentang pasar modal syariah terhadap minat investasi saham di pasar modal syariah Jenis penelitian yang digunakan adalah penelitian verifikatif dengan menggunakan pendekatan kuantitatif. Populasi sebanyak 790 responden, sampel sebanyak 89 responden dengan menggunakan pengambilan sampel non Porbability sampling, yakni teknik purposive sampling. Variabel independen yaitu pengetahuan tentang pasar modal syariah $(X)$ dan variabel dependen yaitu minat investasi saham di Pasar Modal Syariah (Y). Pengumpulan data menggunakan dua teknik yaitu kepustakaan dan kuesioner. Penelitian ini menggunakan metode analisis regresi linear sederhana yang mempunyai bentuk persamaan $\mathrm{Y}=\mathrm{a}+\mathrm{bX}$ dengan bantuan program komputer IBM SPSS for Windows Relese 21.0. Untuk menganalisis pengaruh variabel independen terhadap variabel dependen digunakan uji-t. Hasil pengujian menunjukkan bahwa pengaruh pengetahuan tentang pasar modal syariah memiliki pengaruh signifikan terhadap minat investasi saham dipasar modal syariah pada mahasiswa FEBI IAIN Palu angkatan 2017-2018, dengan nilai signifikan $0,000<0,05$, serta nilai $t_{\text {hitung }} 8,734>$ nilai $t_{\text {tabel }} 1,663$. Implikasi dalam penelitian ini adalah bagi mahasiswa terlebih dahulu harus menggali, mengetahui dan memahami berbagai informasi tentang pasar modal syariah sebelum berinvestasi saham di pasar modal syariah.
INFORMASI

ARTIKEL

Katakunci:

Pengetahuan, Pasar Modal Syariah, Investasi, Saham 


\section{PENDAHULUAN}

Perkembangan ekonomi dan teknologi komunikasi yang sangat pesat memberikan begitu banyak kemudahan dalam dunia bisnis. Hal ini terlihat dengan banyaknya perusahaanperusahaan yang berdiri dan berkembang dengan memanfaatkan fasilitas teknologi. Selain itu, perkembangan bisnis ini juga berdampak pada meningkatnya daya saing antar perusahaan sehingga setiap perusahaan dituntut untuk selalu mengembangkan strateginya. Salah satu bentuk perusahaan dalam menunjang kinerja perusahaan adalah dengan bergabung di Pasar Modal.

Aktivitas pasar modal di indonesia dimulai sejak tahun 1912 di Jakarta. Efek yang diperdagangkan pada saat itu adalah saham milik perusahaan orang Belanda dan obligasi yang diperdagangkan adalah obligasi milik pemerintah Hindia Belanda. Aktivitas pasar modal ini berhenti ketika terjadi perang dunia II. Ketika Indonesia merdeka, pemerintah menerbitkan obligasi pada tahun 1950. Pengaktifan pasar modal di jakarta ini ditandai dengan diterbitkan Undang-Undang darurat tentang Bursa Nomor 13 Tahun 1951 yang kemudian ditetapkan dengan Undang-Undang Nomor 15 tahun 1952 yang berkaitan dengan pasar modal. ${ }^{1}$

Pasar modal memiliki peran penting dalam menunjang perekonomian suatu negara dikarenakan pasar modal memiliki dua fungsi sekaligus, yaitu fungsi ekonomi dan fungsi keuangan. Pasar modal ialah tempat bertemunya antara pihak yang memiliki kelebihan dana (investor)

1Abdul Manan, Aspek Hukum Dalam Penyelenggaraan Investasi Di Pasar Modal Syariah Indonesia (Cet. II; Jakarta: Kencana 2017), 13. dengan pihak yang membutuhkan dana (perusahaan) dengan cara memperjualbelikan sekuritas. Hadirnya pasar modal memiliki peran penting bagi para investor, baik investor individu maupun badan usaha. Mereka dapat menyalurkan kelebihan dana yang dimilikinya untuk di investasikan, sehingga para pengusaha dapat memperoleh dana tambahan modal untuk memperluas jaringan usahannya dari para investor yang berada di pasar modal. ${ }^{2}$

Untuk mendorong perkembangan pertumbuhan ekonomi di Indonesia, yang penduduknya mayoritas muslim, kemajuan pasar modal syariah telah muncul dengan perkembangan pasar modal syariah melalui diterbitkannya reksa dana syariah oleh PT. Danareksa Investment Management pada 03 Juli 1997, selanjutnya Bursa Efek Indonesia bekerja sama dengan PT. Danareksa Investment Management meluncurkan Jakarta Islamic Index (JII) pada tanggal 03 Juli 2000 yang bertujuan untuk memandu investor yang ingin menginvestasikan dananya secara syariah, ditopang oleh fatwa mengenai pasar modal syariah pada tanggal 18 April 2001 oleh Dewan Syariah Nasional Majelis Ulama Indonesia (DSN- MUI), serta obligasi efektif mulai 30 Oktober 2002.3

Munculnya pasar saham syariah adalah kunci untuk mengurangi risiko

2Rizki Chaerul Pajar, "Pengaruh Motivasi Investasi dan Pengetahuan Investasi Terhadap Minat Investasi di Pasar Modal Pada Mahasiswa FE UNY". (Skripsi Tidak diterbitkan, jurusan ekonomi, Universitas Negeri Yogyakarta, Yogyakarta, 2017), 1

3Otoritas Jasa Keuangan (OJK), "Pasar Modal Syariah," Situs Resmi OJK. https:// www.ojk.go.id/id/kanal/pasarmodal/Pages/Syariah.aspx (13 Agustus 2020) 
ketidakpastian dalam pasar modal konvensional, tidak hanya itu, pasar saham syariah menampung masyarakat (muslim dan non muslim) dalam kegiatan memperoleh keuntungan dan risikonya, meningkatkan performa, kinerja dan sustainable dari perusahaan yang termasuk dalam bursa saham syariah sesuai dengan harga saham, serta mengurangi terjadinya spekulasi di pasar modal. ${ }^{4}$

Pasar modal syariah adalah kegiatan ekonomi muamalah yang memperjualbelikan surat berharga yang menurut investasi syariah yaitu saham syariah, obligasi/sukuk dan reksadana syariah. Pasar modal syariah dikembangkan dalam rangka mengakomodir kebutuhan umat Islam di Indonesia yang ingin melakukan investasi di produk-produk pasar modal yang sesuai dengan prinsip dasar syariah. ${ }^{5}$

Salah satu produk yang dijual di pasar modal adalah saham, sebab pasar modal ini merupakan alternatif pendanaan bagi perusahaan-perusahaan yang pada akhirnya memberikan kemakmuran bagi masyarakat. Oleh karena itu, saham dapat didefinisikan sebagai tanda penyertaan atau tanda kepemilikan seseorang atau badan dalam suatu perusahaan atau perusahaan terbatas. Wujud saham

${ }^{4}$ Ahmad Dahlan Malik, "Analisa FaktorFaktor Yang Mempengaruhi Minat Masyarakat Berinvestasi Di Pasar Modal Syariah Melalui Bursa Galeri Investasi UISI" Ekonomi Dan Bisnis Islam Vol. 3 No. 1 (Januari-Juli), 63. https://ejournal.unair.ac.id/index.php/JEBIS/article/vie w/4693 (20 September 2020)

${ }^{5}$ Adrian Sutedi, Pasar Modal Syariah :Sarana Investasi Keuangan Berdasarkan Prinsip Syariah (Cet. I; Jakarta: Sinar Grafika, 2011), 10 berupa selembar kertas yang menerangkan siapa pemiliknya. ${ }^{6}$

Saham merupakan surat berharga bukti penyertaan modal kepada perusahaan dan dengan bukti penyertaan tersebut pemegang saham berhak untuk mendapatkan bagian hasil dari usaha perusahaan tersebut. Konsep penyertaan modal dengan hak bagian hasil usaha ini merupakan konsep yang tidak bertentangan dengan prinsip syariah. Prinsip syariah mengenal konsep ini sebagai kegiatan musyarakah atau syirkah. Berdasarkan analogi tersebut, maka secara konsep saham merupakan efek yang tidak bertentangan dengan prinsip syariah. ${ }^{7}$

investasi adalah menanamkan modal atau menempatkan aset, baik berupa harta maupun dana, pada sesuatu yang diharapkan akan memberikan hasil pendapatan atau akan meningkatkan nilainya dimasa mendatang. Atau secara sederhana, investasi berarti mengubah casflow agar mendapatkan keuntungan atau jumlah yang lebih besar dikemudian hari. 8

Berdasarkan survei yang dilakukan BEI, Nielsen, dan Universitas Indonesia, diketahui bahwa usia muda berpotensi besar menjadi investor saham. Dari hasil studi tersebut ternyata pemilikan saham mulai menjadi bagian gaya hidup masyarakat. Tren dalam membeli barang-barang mewah dan bermerek untuk dijadikan instrumen investasi mulai menyurut. Belakangan ini, publik kembali melirik investasi di pasar modal melalui share saving. Hal ini

${ }^{6}$ Abdul Manan, Aspek Hukum Dalam Penyelenggaraan Investasi Di Pasar Modal Syariah (Cet. II; Jakarta: Kencana, 2017), 94

7Ibid

${ }^{8}$ Muhammad Firdaus, Sistem Keuangan $\mathcal{E}$ Investasi Syariah (Cet. I; Jakarta: Reanaisan, 2005), 12 
tak lepas dari gerakan kampanye yang dilakukan oleh PT Bursa Efek Indonesia (BEI). ${ }^{9}$

Institut Agama Islam Negeri (IAIN) Palu, merupakan salah satu perguruan tinggi Negeri Islam yang telah mempunyai galeri investasi syariah, dibukanya galeri ini merupakan kerja sama antara Fakultas Ekonomi dan Bisnis Islam dengan BEI (Bursa Efek Indonesia) Sulawesi tengah. Dengan adanya galeri investasi syariah bisa dimanfaatkan oleh mahasiswa maupun masyarakat umum yang akan melakukan investasi dibidang saham syariah.

Mahasiswa dapat mulai untuk berinvestasi di beberapa sektor salah satunya di pasar modal, demi memiliki kondisi finansial yang lebih baik di masa depan. Sebagai mahasiswa, seringkali dana menjadi kendala utama dalam melakukan investasi terutama bagi mahasiswa yang mayoritas penghasilanya didapatkan dari kiriman orang tua. Jika dilihat secara umum, sumber keuangan mahasiswa bisa diperoleh dengan beberapa cara yakni (1) pemberian dari orang tua, (2) beasiswa, (3) uang yang berasal dari hadiah atau bonus, (4) dan yang terakhir berasal dari pendapatan pribadi/pekerjaan sampingan yang dimiliki. Dengan adanya sumber keuangan mahasiswa tersebut dan ditambah lagi pengetahuan tetang pasar modal syariah diharapkan dapat mampu menumbuhkan rasa minat bagi mahasiswa untuk berinvestasi saham di pasar modal syariah.

${ }^{9}$ Rizki Chaerul Fajar, "Pengaruh Motivasi Investasi Dan Pengetahuan Investasi Terhadap Minat Investasi Di Pasar Modal Pada Mahasiswa FE UNY" (Skripsi Tidak Diterbitkan, Program Studi Akuntansi, UNY, Yogyakarta, 2017), 7
Pengetahuan mengenai pasar modal syariah dan investasi juga diedukasikan pada mahasiswa khususnya mahasiswa yang mengambil jurusan ekonomi syariah dan perbankan syariah Fakultas Ekonomi dan Bisnis Islam IAIN Palu. Mahasiswa sangat perlu dibimbing untuk mengenal investasi di pasar modal syariah lebih dini sehingga mereka tidak konsumtif dan mulai menyiapkan kemampuan finansial. ${ }^{10}$ Edukasi mengenai pasar modal syariah ini diperoleh dari mata kuliah seperti bank dan lembaga keuangan syariah, Manajemen Keuangan dan Investasi Syariah. Berbagai aspek dipelajari dalam mata kuliah yang menyangkut pasar modal syariah dan investasi mulai dari jenisjenis investasi, manfaat investasi, hingga resiko-resiko yang akan dihadapi. Beberapa fasilitas penunjang juga telah disediakan yakni dengan adanya galeri investasi syariah sebagai media pembelajaran real untuk terjun langsung kedunia investasi di pasar modal syariah.

\section{TINJAUAN PUSTAKA}

\subsection{Pengetahuan Pasar Modal Syariah}

Pengetahuan berasal dari kata latin (scientia) dan bahasa Inggris (science) yang berarti ilmu. Kata scientia berasal dari bentuk kata kerja "scire" yang artinya mempelajari, mengetahui. Jadi pengetahuan adalah semua yang diketahui. Namun pengetahuan dapat

10Siti Latifah, "Pengaruh Pengetahuan, Modal Minimal dan Motivasi Investasi Terhadap Minat Mahasiswa Untuk Berinvestasi Di Pasar Modal Syariah". (Skripsi Tidak diterbitkan, Jurusan Ekonomi Syariah, Institut Agama Islam Negeri (IAIN) Purwokerto, Purwokerto, 2019), 5 
diartikan juga sebagai informasi yang disaring dan dimaknai. ${ }^{11}$

1) Tahu (know)

Diartikan hanya sebagai recall (memanggil) memori yang telah ada sebelumnya setelah mengamati seuatu. Untuk mengetahui atau mengukur bahwa orang tahu sesuatu dapat menggunakan pertanyaan-pertanyaan.

2) Memahami (comprehension)

Memahami suatu objek bukan sekedar tahu terhadap objek tersebut, tidak sekedar dapat menyebutkan, tetapi orang tersebut harus dapat menginterprestasiakan secara benar tentang oobjek yang diketahui tersebut.

3) Aplikasi (aplication)

Aplikasi diartikan apabila orang yang telah memahami objek yang dimaksud dapat menggunakan atau mengaplikasikan prinsip yang diketahui tersebut pada situasi lain.

4) Analisa (analisys)

Analisis adalah kemampuan seseorang untuk menjabarka dan/ atau memisahkan, kemudian mencari hubungan antara komponen-komponen yang terdapat dalam suatu masalah atau objek yang diketahui.

5) Sintesis (synthesis)

Sintesis menunjukan suatu kemampuan seseorang untuk merangkum atau meletakkan dalam satu hubungan yang logis dari komponen-komponen pengetahuan yang dimiliki.

6) Evaluasi (evaluation)

Evaluasi berkaitan dengan kemampuann seseorang untuk

\footnotetext{
${ }^{11}$ Alex Sobur, Psikologi Umum Dalam Lintasan Sejarah, ( Cet. I; Bandung: Pustaka Setia, 2010), 34
}

melakukan justifikasi atau penilaian terhadap suatu objek tertentu. ${ }^{12}$

Pengetahuan dimulai dari rasa ingin tahu, artinya hasil pekerjaan tahu. Hasil pekerjaan tahu merupakan isi seluruh pikiran disebut pengetahuan. Pengetahuan merupakan pengalaman indra (penglihatan, pendengaran, rasa, perabaan dan penciuman segala sesuatu) melalui proses pemikiran, ranahnya segala sesuatu yang dapat disentuh oleh pancaindra secara langsung, batasannya sampai kepada segala sesuatu yang tidak tertangkap oleh indra. ${ }^{13}$

Pasar Modal Syariah adalah suatu kegiatan ekonomi muamalah yang memperjualbelikan surat berharga yang menurut investasi syariah yaitu saham, obligasi dan reksadana syariah. Pasar modal syariah dikembangkan dalam rangka mengakomodir kebutuhan umat islam Indonesia yang ingin melakukan investasi di produk- produk pasar modal yang sesuai dengan prinsip syariah. ${ }^{14}$

Berdasarkan definisi diatas, pengetahuan pasar modal syariah adalah pengetahuan yang didapatkan dari memahami dan mempelajari pasar modal syariah sehingga dapat di implementasikan.

${ }^{12 N u r d i n ~ N u r d i n, ~ W i n d a ~ N u r ~ A z i z a h, ~}$ Rusli Rusli, "Pengaruh Pengetahuan, Kemudahan dan Risiko Terhadap Minat Bertransaksi Menggunakan Finansial Technology (Fintech) Pada Mahasiswa Institut Agama Islam Negeri (IAIN) Palu", Jurnal Perbankan dan Keuangan Syariah Vol. 2 no.2 (Tahun 2020), 203. https://jurnaljipsya.org/index.php/jipsya/artic le/view/32 (25 Mei 2021)

13Juliansyah Noor, Penelitian Ilmu Manajemen, (Cet. I; Jakarta: Kencana, 2013), 7

${ }^{14}$ Adrian Sutedi, Pasar Modal Syariah: Sarana Investasi Keuangan Berdasarkan Prinsip Syariah (Cet.1; Jakarta: Sinar Grafika, 2011), 24. 
a. Sejarah pasar modal syariah

Sejarah Pasar Modal Syariah di Indonesia dimulai dengan diterbitkannya Reksa Dana Syariah oleh PT. Danareksa Investment Management pada 3 Juli 1997. Selanjutnya, Bursa Efek Indonesia berkerjasama dengan PT. Danareksa Investment Management meluncurkan Jakarta Islamic Index pada tanggal 3 Juli 2000 yang bertujuan untuk memandu investor yang ingin menginvestasikan dananya secara syariah. Dengan hadirnya indeks tersebut, maka para pemodal telah disediakan saham-saham yang dapat dijadikan sarana berinvestasi sesuai dengan prinsip syariah. ${ }^{15}$

Pada tanggal 18 April 2001, untuk pertama kali Dewan Syariah Nasional Majelis Ulama Indonesia (DSN-MUI) mengeluarkan fatwa yang berkaitan langsung dengan pasar modal, yaitu Fatwa Nomor 20/DSN-MUI/IV/2001 tentang Pedoman Pelaksanan Investasi Untuk Reksa Dana Syariah. Selanjutnya, instrumen investasi syariah di pasar modal terus bertambah dengan kehadiran Obligasi Syariah PT. Indosat Tbk pada awal September 2002. Instrumen ini merupakan Obligasi Syariah pertama dan akad yang digunakan adalah akad mudharabah. ${ }^{16}$

Sejarah Pasar Modal Syariah juga dapat ditelusuri dari perkembangan institusional yang terlibat dalam pengaturan Pasar Modal Syariah tersebut. Perkembangan tersebut dimulai dari MoU antara Bapepam dan DSN-MUI pada tanggal 14 Maret 2003. MoU menunjukkan adanya

${ }^{15}$ Otoritas Jasa Keuangan (OJK), “Pasar Modal Syariah," Situs Resmi OJK. https://www.ojk.go.id/id/kanal/syariah/Page s/Pasar-Modal-Syariah.aspx (12 September 2020)

16Ibid kesepahaman antara Bapepam dan DSN-MUI untuk mengembangkan pasar modal berbasis syariah di Indonesia. ${ }^{17}$

Dari sisi kelembagaan BapepamLK, perkembangan Pasar Modal Syariah ditandai dengan pembentukan Tim Pengembangan Pasar Modal Syariah pada tahun 2003. Selanjutnya, pada tahun 2004 pengembangan Pasar Modal Syariah masuk dalam struktur organisasi Bapepam dan LK, dan dilaksanakan oleh unit setingkat eselon IV yang secara khusus mempunyai tugas dan fungsi mengembangkan pasar modal syariah. Sejalan dengan perkembangan industri yang ada, pada tahun 2006 unit eselon IV yang ada sebelumnya ditingkatkan menjadi unit setingkat eselon III. ${ }^{18}$

Pada tanggal 23 November 2006, Bapepam-LK menerbitkan paket Peraturan Bapepam dan LK terkait Pasar Modal Syariah. Paket peraturan tersebut yaitu Peraturan Bapepam dan LK Nomor IX.A13 tentang Penerbitan Efek Syariah dan Nomor IX.A.14 tentang Akad-akad yang digunakan dalam Penerbitan Efek Syariah di Pasar Modal. Selanjutnya, pada tanggal 31 Agustus 2007 Bapepam-LK menerbitkan Peraturan Bapepam dan LK Nomor II.K.1 tentang Kriteria dan Penerbitan Daftar Efek Syariah dan diikuti dengan peluncuran Daftar Efek Syariah pertama kali oleh Bapepam dan LK pada tanggal 12 September 2007.19

Perkembangan Pasar Modal Syariah mencapai tonggak sejarah baru dengan disahkannya UU Nomor 19 tahun 2008 tentang Surat Berharga Syariah Negara (SBSN) pada tanggal 7 Mei 2008. Undang-undang ini

17Ibid

18Ibid

19Ibid 
diperlukan sebagai landasan hukum untuk penerbitan surat berharga syariah negara atau sukuk negara. Pada tanggal 26 Agustus 2008 untuk pertama kalinya Pemerintah Indonesia menerbitkan SBSN seri IFR0001 dan IFR0002. ${ }^{20}$

Pada tanggal 30 Juni 2009, Bapepam-LK telah melakukan penyempurnaan terhadap Peraturan Bapepam-LK Nomor IX.A.13 tentang Penerbitan Efek Syariah dan II.K.1 tentang Kriteria dan Penerbitan Daftar Efek Syariah. ${ }^{21}$

b. Pengertian pasar modal syariah

Pasar modal adalah perdagangan instrument keuangan (sekuritas) jangka panjang, antara lain: dalam bentuk modal sendiri (stock) maupun utang (bonds); baik yang diterbitkan oleh pemerintah (public authorities) maupun oleh perusahaan swasta (private sector). Sedangkan pasar modal syariah merupakan tempat atau sarana bertemunya penjual dan pembeli instrumen keuangan syariah yang dalam berinteraksi berpedoman pada ajaran islam dan menjauhi hal-hal yang dilarang, seperti penipuan, ribawi dan penggelapan. 22

Allah berfirman dalam Q.S. AlBaqarah/2: 278.

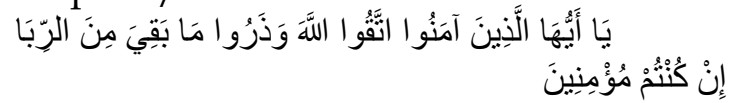

Terjemahanya:

"Hai orang-orang yang beriman, bertakwalah kepada Allah dan tinggalkan sisa riba (yang belum dipungut) jika kamu orang-orang yang beriman." 23

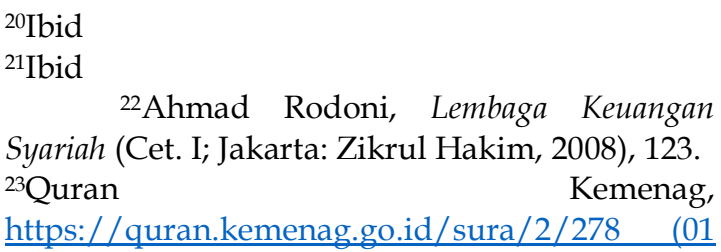

Februari 2021)
Diartikan sebagai kegiatan dalam pasar modal sebagaimana yang diatur dalam UUPM yang tidak bertentangan dengan prinsip syariah. Oleh karena itu, pasar modal syariah bukanlah suatu sistem yang terpisah dari sistem pasar modal secara keseluruhan. Secara umum kegiatan Pasar Modal Syariah tidak memiliki perbedaan dengan pasar modal konvensional, namun terdapat beberapa karakteristik khusus Pasar Modal Syariah yaitu bahwa produk dan mekanisme transaksi tidak bertentangan dengan prinsip-prinsip syariah Penerapan prinsip syariah di pasar modal tentunya bersumberkan pada $\mathrm{Al}$ Quran sebagai sumber hukum tertinggi dan Hadits Nabi Muhammad SAW. ${ }^{24}$

Selanjutnya, dari kedua sumber hukum tersebut para ulama melakukan penafsiran yang kemudian disebut ilmu fiqih. Salah satu pembahasan dalam ilmu fiqih adalah pembahasan tentang muamalah, yaitu hubungan diantara sesama manusia terkait perniagaan. Berdasarkan itulah kegiatan pasar modal syariah dikembangkan dengan basis fiqih muamalah.Terdapat kaidah fiqih muamalah yang menyatakan bahwa Pada dasarnya, semua bentuk muamalah boleh dilakukan kecuali ada dalil yang mengharamkannya. Konsep inilah yang menjadi prinsip pasar modal syariah di Indonesia. ${ }^{25}$

\subsection{Minat Investasi Saham}

a. Pengertian minat investasi saham

Menurut Slameto minat adalah suatu rasa lebih suka dan rasa

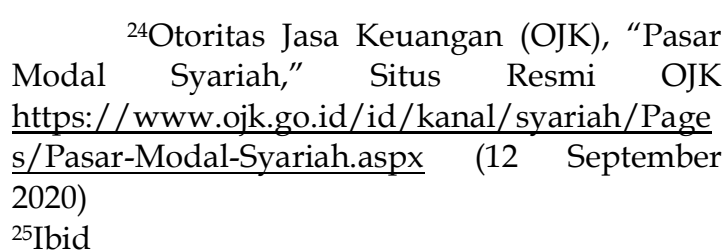


ketertarikan pada suatu hal atau aktivitas tanpa ada yang menyuruh. ${ }^{26}$ Menurut Mahfud Shalahuddin, minat adalah perhatian yang mengandung unsur-unsur perasaan, minat adalah suatu sikap yang menyebabkan seseorang berbuat aktif dalam suatu pekerjaan. Dengan kata lain minat menjadi sebab dari suatu kegiatan. ${ }^{27}$

Minat adalah rasa lebih suka dan rasa ketertarikan pada suatu hal atau aktivitas. ${ }^{28}$ Minat pada dasarnya adalah penerimaan akan suatu hubungan antara diri sendiri dengan sesuatu diluar diri. Semakin kuat dan dekat hubungan tersebut, semakin besar minatnya. Crow and Crow mengatakan bahwa minat berhubungan dengan gaya gerak yang mendorong seseorang untuk menghadapi atau berurusan dengan orang, benda, kegiatan, pengalaman yang dirangsang oleh kegiatan itu sendiri. Jadi minat dapat diekspresikan melalui pernyataan yang menujukkan bahwa lebih menyukai suatu hal daripada hal lainnya, dapat pula di manifestasikan melalui partisipasi dalam suatu aktivitas. Minat tidak

26Slameto, Belajar Dan Faktor-Faktor Yang Mempengaruhinya, (Cet. VI; Jakarta: Rineka Cipta, 2015). 180

${ }^{27}$ Abdul Jalil, Sitti Azizah Hamzah, "Pengaruh Bagi Hasil dan Kebutuhan Modal Terhadap Minat UMKM Mengajukan Pembiayaan Pada Lembaga Keuangan Syariah di Kota Palu", Jurnal Perbankan dan Keuangan Syariah Vol. 2 no. 2 (Tahun 2020), 190. https://jurnaljipsya.org/index.php/jipsya/artic le/view/31 (25 Mei 2021)

28 Nurdin, N., Musyawarah, I., Nurfitriani, N., \& Jalil, A. (2020). Pengaruh Pelayanan Mobile Banking Terhadap Kepuasan Nasabah (Studi Pada Mahasiswa Perbankan Syariah IAIN Palu) Jurnal Ilmu Perbankan dan Keuangan Syariah, 2(2), 87-104. dibawa sejak lahir,melainkan diperoleh kemudian. ${ }^{29}$

Dalam kamus istilah Pasar Modal dan Keuangan kata investasi di artikan sebagai penanaman uang atau modal dalam suatu perusahaan atau proyek untuk tujuan memperoleh keuntungan. Dan dalam Kamus Lengkap Ekonomi, investasi didefinisikan sebagai penukaran uang dengan bentuk-bentuk kekayaan lain seperti saham atau harta tidak bergerak yang diharapkan dapat ditahan selama periode waktu tertentu supaya menghasilkan pendapatan. ${ }^{30}$ Menurut Irham Fahmi, investasi dapat didefinisikan sebagai bentuk pengelolaan dana guna memberikan keuntungan dengan cara menempatkan dana tersebut pada alokasi yang diperkirakan akan memberikan tambahan keuntungan atau coumpounding.

Definisi investasi adalah menanamkan modal atau menempatkan aset, baik berupa harta maupun dana, pada sesuatu yang diharapkan akan memberikan hasil pendapatan atau akan meningkatkan nilainya dimasa mendatang. Atau secara sederhana, investasi berarti mengubah casflow agar mendapatkan keuntungan atau jumlah yang lebih besar dikemudian hari. ${ }^{31}$

${ }^{29}$ Djaali, Psikologi Pendidikan,(Cet. I; Jakarta: Bumi Aksara, 2018).121

${ }^{30}$ Ari Wibowo, Pengaruh Pengetahuan Investasi,Kebijakan Modal Minimal Investasi dan Pelatihan Pasar Modal Terhadap Minat Investasi, Jurnal Ilmu Manajemen, vol. 7 no. 1 (Oktober 2019), 198. https://jurnalmahasiswa.unesa.ac.id/index.php Ljim/article/view/25386 (27 September 2020)

${ }^{31}$ Muhammad Firdaus, Sistem Keuangan $\mathcal{E}$ Investasi Syariah (Cet. I; Jakarta: Reanaisan, 2005), 12 
Saham adalah sertifikat yang menunjukan bukti kepemilikan suatu perusahaan, dan pemegang saham memiliki hak klaim atas penghasilan dan aktiva perusahaan. ${ }^{32}$

Berdasarkan devinisi di atas Minat investasi saham merupakan suatu keinginan untuk menempatkan sebagian dananya yang berupa saham pada pasar modal dengan maksud mendapatkan keuntungan di masa depan.

b. Harga Saham

Harga sebuah saham sangat dipengaruhi oleh hukum permintaan dan penawaran. Harga suatu saham akan cenderung naik apabila suatu saham mengalami kelebihan permintaan dan cenderung turun jika terjadi kelebihan penawaran.

Ada dua macam analisis untuk menentukan harga saham, yaitu: 33

1) Analisis teknikal (technical analysis), yaitu menentukan harga saham dengan menggunakan data pasar dari saham, misalnya harga saham, volume transaksi saham, dan indeks pasar;

2) Analisis fundamental (fundamental analysis) atau analisis perusahaan (company analysis), yaitu menentukan harga saham dengan menggunakan data fundamental, yaitu data yang berasal dari keuangan perusahaan, misalnya laba, dividen yang dibayar, penjualan, pertumbuhan, dan prospek perusahaan serta kondisi industri perusahaan. Terjadinya perbaikan prestasi kondisi fundamental perusahaan (kinerja keuangan dan operasional perusahaan), biasannya diikuti

\footnotetext{
${ }^{32}$ Khaerul Umam, Pasar Modal Syariah \& Praktik Pasar Modal Syariah (Cet. I; Bandung: Pustaka Setia, 2013), 113

${ }^{33}$ Ibid, 114
}

dengan kenaikan harga saham di lantai bursa.

c. Indeks Saham

Indeks saham merupakan salah satu indikator pergerakan harga saham. Salah satu fungsi indeks adalah sebagai indikator trend pasar, artinya pergerakan indeks menggambarkan kondisi trend pasar ketika sedang aktif ataupun sedang.

jenis indeks saham di bursa efek indonesia, yaitu: ${ }^{34}$

1) Indeks harga saham individu (IHSI) atau indeks saham individu adalah indeks masing-masing harga pasar saham terhadap harga dasar saham.

2) Indeks harga saham gabungan (IHSG) diperkenalkan tanggal 1 April 1983. IHSG mencakup seluruh pergerakan harga saham dari berbagai jenis saham, baik saham biasa maupun saham preferen, yang terdaftar di Bursa Efek Indonesia.

3) Indeks sektoral, diperkenalkan tanggal 2 januari 1996. Indeks sektoral merupakan bagian dari IHSG. Semua perusahaan yag tercatat di bursa efek indonesia diklasifikasikan dalam 9 sektor berdasarkan klasifikasi industri. Klasifikasi ini ditetapkan oleh Jakarta Stock Exchange Industri (JASICA).

4) Indeks LQ45, diperkenalkan tanggal 13 Juli 1994. Indeks LQ45 terdiri atas 45 saham yang dipilih setelah melalui seleksi beberapa kriteria tertentu, sehingga indeks ini terdiri atas saham yang mempunyai kriteria likuiditas tinggi dan kapitalisasi pasar tinggi. Untuk menjamin kewajaran dalam seleksi saham, Bursa Efek Indonesia memiliki komite penasihat yang terdiri atas kalangan praktisi,

${ }^{34}$ Ibid, 117 
akademisi, dan profesional independen di bidang pasar modal.

5) Indeks syariah (Jakarta Islamic Index), diperkenalkan tanggal 1 Januari 1995. Indeks syariah diluncurkan pertama kali oleh Bursa Efek Indonesia bekerja sama dengan Dewan Pengawas Syariah PT Danareksa Investment Management. Kriteria indeks syariah didasarkan pada syariah islam. Indeks syariah terdiri atas 30 saham.

Jenis saham ada dua, yaitu saham biasa (common stock) dan saham preferen (preferred stock). ${ }^{35}$

1) Saham biasa (common stock), secara sederhana, dapat didefinisikan sebagai tanda penyertaan atau pemilikan seorang atau badan dalam suatu perusahaan. Wujud saham adalah selembar kertas yang menerangkan bahwa pemilik kertas tersebut adalah pemilik perusahaan yang menerbitkan kertas tersebut.

2) Saham preferen (preferred stock), saham preferen merupakan saham yang memiliki karakteristik gabungan antara obligasi dan saham biasa karena bisa menghasilkan pendapatan tetap (seperti bunga obligasi), tetapi juga bisa tidak mendatang hasil seperti yang dikehendaki investor. Secara praktis saham preferen dipandang sebagai surat berharga dengan pendapatan tetap dan karena itu akan bersaing dengan obligasi di pasar. Walaupun demikian, obligasi perusahaan menduduki tempat yang lebih senior dibanding dengan saham preferen.

\section{d. Return Saham}

Return saham adalah keuntungan yang dinikmati investor atas investasi saham yang dilakukannya. Return

\footnotetext{
${ }^{35}$ Ibid, 118
}

tersebut memiliki dua komponen, yaitu current income dan capital gain. Bentuk current income berupa keuntungan yang diperoleh melalui pembayaran yang bersifat periodik berupa dividen sebagai hasil kinerja fundamental perusahaan. Adapun capital gain berupa keuntungan yang diterima karena selisih antara harga jual dan harga beli saham. Besarnya capital gain suatu saham akan positif, bilamana harga jual dari saham yang memiliki lebih tinggi dari pada harga belinya. ${ }^{36}$

\section{METHODOLOGY}

Jenis penelitian ini adalah penelitian kuantitatif 37,38 yaitu metode yang bertujuan untuk menguji secara matematis dugaan mengenai adanya hubungan variabel dari masalah yang sedang diselidiki di dalam hipotesis. ${ }^{39}, 40$

Pendekatan yang dilakukan dalam penelitian ini adalah pendekatan

\section{${ }^{36}$ Ibid, 119}

37 Nurdin, N., Pettalongi, S. S., \& Ahsan, M. N. (2019). Implementation of Teaching Quality Assessment System Using Android. Paper presented at the 2019 5th International Conference on Science and Technology (ICST).

38 Nurdin, N., Pettalongi, S. S., \& Mangasing, M. (2019). Understanding Digital Skill Use from The Technology Continuance Theory (TCT). Paper presented at the 2019 6th International Conference on Information Technology, Computer and Electrical Engineering (ICITACEE).

39 Rully indrawan dan poppy

Yuniawati, metode penelitian, (Cet. I, Bandung :

PT. Rafika Aditama, 2004) 117

40 Nurdin, N., Azizah, W. N., \& Rusli, R. (2020). Pengaruh Pengetahuan,Kemudahan dan Risiko Terhadap Minat Bertransaksi Menggunakan Finansial Technology (Fintech) Pada Mahasiswa Institut Agama Islam Negeri (IAIN) Palu Jurnal Ilmu Perbankan dan Keuangan Syariah, 2(2), 199-222. 
kuantitatif, 41 menggunakan pendekatan kuantitatif karena data penelitian tersebut berupa angka-angka dapat ditafsirkan atau dianalisis menggunakan statistik. 42

Adapun lokasi penelitian adalah pada Fakultas Ekonomi dan Bisnis Islam (FEBI) IAIN Palu. Populasi dalam penelitian adalah seluruh mahasiswa FEBI angkatan 2017-2018 dengan jumlah 790 orang. Kemudian sampel dalam peneitian ini diambil dengan menggunakan rumus slovin dan diperoleh 89 yang menjadi sampel penelitian ini dengan teknik purposive sampling.

Teknik analisis data yang digunakan dalam penelitian ini adalah analisis kuantitatif. Yaitu proses analisis yang terdapat data-data yang berbentuk angka dengan cara perhitungan secara statistik untuk mengukur pengaruh pengetahuan terhadap minat berinvestasi di pasar modal syariah. Analisa data dilakukan melalui tahap uji validitas, reabilitas, uji regresi berganda, dan uji asumsi klasik. Untuk pembuktian hipotesis penulis menggunakan uji f dan uji t. ${ }^{43}$

\section{HASIL DAN PEMBAHASAN}

41 Nurdin, N., Musyawarah, I., Nurfitriani, N., \& Jalil, A. (2020). Pengaruh Pelayanan Mobile Banking Terhadap Kepuasan Nasabah (Studi Pada Mahasiswa Perbankan Syariah IAIN Palu) Jurnal Ilmu Perbankan dan Keuangan Syariah, 2(2), 87-104.

42 Sofian Siregar, Statistik Parametrik untuk Penelitian Kuantitatif, Edisi 1, Cet. 3, (Jakarta: PT. Bumi Aksara, 2015), 30.

43 Abdul Jalil . Pengaruh Beban Kerja, Stres Kerja dan Lingkungan Kerja Terhadap Kinerja Guru Madrasah Aliyah Negeri 2 Kota Palu.Jurnal Ilmu Perbankan dan Keuangan Syariah, 1(2), 117-134. 2019

\subsection{Deskripsi Responden Dan Variabel Penelitian \\ Deskripsi responden digunakan} untuk menggambarkan keadaan atau kondisi responden sehingga dapat memberikan informasi tambahan serta memahami hasil-hasil penelitian. Penyajian data deskriptif penelitian ini bertujuan agar dapat dilihat dari data penelitian tersebut serta hubung antara variabel yang digunakan dalam penelitian dengan jumlah responden 89 mahasiswa fakultas FEBI IAIN Palu Angkatan 2017-2018. Dalam penelitian ini peneliti mendiskripsikan data penelitian secara lebih rinci mengenai profil responden serta variabel penelitian. Jumlah responden berdasarkan jenis kelamin dapat dilihat pada tabel 1 berikut ini:

Tabel 1

Responden Berdasarkan Jenis Kelamin

\begin{tabular}{|c|c|c|}
\hline Jenis Kelamin & Frekuensi & Persentase (\%) \\
\hline Laki-Laki & 18 & $20,2 \%$ \\
\hline Perempuan & 71 & $79,8 \%$ \\
\hline Total & 89 & $100 \%$ \\
\hline
\end{tabular}

Sumber: Data Primer yang diolah tahun 2021

Pada tabel 1 menunjukan bahwa dari 89 orang, sampel dalam penelitian ini yang seperti terlihat pada tabel di atas menunjukan bahwa dari 89 responden, sebagian besar merupakan responden perempuan berjumlah 71 orang dengan persentase sebesar $(79,8 \%)$, sedangkan sisanya merupakan responden laki-laki berjumlah 18 orang dengan persentase sebesar $(20,2 \%)$.

Sedangkan ditribusi sampel menurut angkatan dapat dilihat pada tabel 2 berikut ini: 
Tabel 2

Responden Berdasarkan Angkatan

\begin{tabular}{|c|c|c|}
\hline Angkatan & Frekuensi & $\begin{array}{c}\text { Presentase } \\
\text { (\%) }\end{array}$ \\
\hline Angkatan 2017 & 40 & $44,9 \%$ \\
\hline Angkatan 2018 & 49 & $55,1 \%$ \\
\hline Total & 89 & $100 \%$ \\
\hline
\end{tabular}

Sumber: Data Primer yang diolah tahun 2021

Pada tabel 2 menunjukan bahwa dari 89 orang, sampel dalam penelitian ini seperti terlihat pada tabel di atas menunjukan bahwa dari 89 responden, sebagian besar merupakan responden dari angkatn 2018 berjumlah 49 orang dengan persentase sebesar (55,1\%), sedangkan responden angkatan 2017 berjumlah 40 orang dengan persentase sebesar $(44,9 \%)$.

Selanjutnya distribusi sampel berdasarkan proram studi dapat dilihat pada tabel 3 berikut ini:

Tabel 3

Responden berdasarkan Program Studi

\begin{tabular}{|c|c|c|}
\hline Progam Studi & Frekuensi & $\begin{array}{c}\text { Persentase } \\
(\mathbf{\%})\end{array}$ \\
\hline Perbankan Syariah & 38 & $42,7 \%$ \\
\hline Ekonomi Syariah & 51 & $57,3 \%$ \\
\hline Total & 89 & $100 \%$ \\
\hline
\end{tabular}

Sumber: Data Primer yang diolah tahun 2021

Pada tabel 4.3 menunjukan bahwa dari 89 orang, sampel dalam penelitian ini yang seperti terlihat pada tabel di atas menunjukan bahwa dari 89 responden, sebagian besar merupakan responden dari Program Studi Ekonomi Syariah berjumlah 51 orang dengan persentase sebesar (57,3\%), dan Program Studi Perbankan Syariah berjumlah 38 orang dengan persentase sebesar $(42,7 \%)$.

\subsection{Deskripsi Variabel}

a. Pengetahuan Tentang Pasar Modal Syariah (X)

Deskripsi responden sebanyak 89 orang terhadap pernyataan pengetahuan tentang pasar modal syariah sebagai berikut:

\begin{tabular}{|c|c|c|c|c|c|c|c|c|c|}
\hline \\
\hline \multirow{2}{*}{\multicolumn{10}{|c|}{ 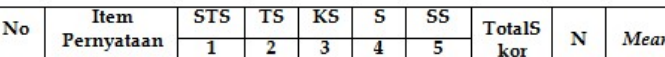 }} \\
\hline & & & & \multicolumn{3}{|c|}{ 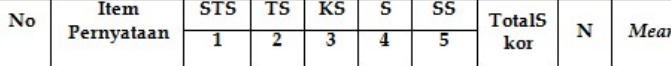 } & & & \\
\hline \multicolumn{10}{|c|}{\begin{tabular}{l|l|l|l|l|l|l|l|l|l} 
& & & & & & & & & \\
1. & Pernyataan 1 & 2 & 1 & 4 & 64 & 18 & 362 & 89 & $\mathbf{4 , 0 7}$
\end{tabular}} \\
\hline 2. & Pernyataan 2 & 4 & 6 & 17 & 54 & 8 & 323 & 89 & 3,63 \\
\hline 3. & Pernyataan 3 & 1 & 3 & 3 & 58 & 24 & 368 & 89 & 4,13 \\
\hline 4. & Pernyataan 4 & 1 & - & 2 & 55 & 31 & 382 & 89 & 4,29 \\
\hline 5. & Pernyataan 5 & 1 & - & 6 & 62 & 20 & 367 & 89 & 4,12 \\
\hline 6. & Pernyataan 6 & 3 & 9 & 16 & 46 & 15 & 328 & 89 & 3,69 \\
\hline 7. & Pernyataan 7 & 1 & - & 7 & 62 & 19 & 365 & 89 & 4,10 \\
\hline 8. & Pernyataan 8 & 1 & - & 4 & 73 & 11 & 360 & 89 & 4,04 \\
\hline 9. & Pernyataan 9 & 1 & 4 & 16 & 61 & 7 & 336 & 89 & 3,78 \\
\hline 10. & $\begin{array}{l}\text { Pernyataan } \\
10\end{array}$ & 1 & 1 & 18 & 60 & 9 & 342 & 89 & 3,84 \\
\hline 11. & $\begin{array}{l}\text { Pernyataan } \\
11\end{array}$ & 1 & 3 & 12 & 50 & 23 & 358 & 89 & 4,02 \\
\hline 12 & $\begin{array}{l}\text { Pernyataan } \\
12\end{array}$ & 2 & 7 & 30 & 43 & 7 & 313 & 89 & 3,52 \\
\hline 13. & $\begin{array}{l}\text { Pernyataan } \\
13\end{array}$ & 1 & 2 & 15 & 64 & 7 & 341 & 89 & 3,83 \\
\hline
\end{tabular}

Berdasarkan tabel 4 diatas menunjukan bahwa nilai Mean dari pernyataan 1 yaitu 4,07, Pernyataan 2 yaitu 3,63, pernyataan 3 yaitu 4,13, pernyataan 4 yaitu 4,29, pernyataan 5, 4,12 , pernyataan 5 yaitu 4,12 , pernyataan 6 yaitu, 3,69, pernyataan 7 yaitu 4,10, pernyataan 8 yaitu 4,04, pernyataan 9 yaitu 3,78, pernyataan 10 yaitu, 3,84, pernyataan 11 yaitu, 4,02, pernyataan 12 yaitu 3,52 , dan pernyataan 13 yaitu 3,83 . b. Minat Investasi Saham (Y)

Deskripsi dari resonden penelitian ini yang berjumlah 89 orang terhadap pernyataan minat berinvestasi saham sebagai berikut:

\begin{tabular}{|c|c|c|c|c|c|c|c|c|c|}
\hline & Nilai & Mean & da & $\begin{array}{l}\text { Tab } \\
\text { rriabe }\end{array}$ & $\begin{array}{l}15 \\
\text { Min }\end{array}$ & Inve & asi Sah & & \\
\hline \multirow[t]{2}{*}{ No } & \multirow{2}{*}{$\begin{array}{c}\text { Item } \\
\text { Pernyataan }\end{array}$} & STS & TS & KS & S & SS & \multirow{2}{*}{$\begin{array}{c}\begin{array}{c}\text { Totals } \\
\text { kor }\end{array}\end{array}$} & \multirow[b]{2}{*}{$\mathbf{N}$} & \multirow[b]{2}{*}{ Mean } \\
\hline & & 1 & 2 & 3 & 4 & 5 & & & \\
\hline 1. & Pernyataan 1 & 1 & 1 & 7 & 63 & 17 & 361 & 89 & 4,06 \\
\hline 2. & Pernyataan 2 & 2 & 2 & 7 & 62 & 16 & 355 & 89 & 3,99 \\
\hline 3. & Pernyataan 3 & 1 & - & 5 & 52 & 31 & 379 & 89 & 4,26 \\
\hline 4. & Pernyataan 4 & 1 & - & 2 & 44 & 42 & 393 & 89 & 4,42 \\
\hline
\end{tabular}

Berdasarkan tabel 5 diatas menunjukan bahwa nilai Mean dari pernyataan 1 yaitu 4,06, Pernyataan 2 
yaitu 3,99, pernyataan 3 yaitu 4,26, dan pernyataan 4 yaitu 4,42 .

\subsection{Analisis Data}

Analisis data yaitu proses analisis yang terdapat data-data yang berbentuk angka dengan cara perhitungan secara statistik untuk mengukur pengaruh pengetahuan tentang pasar modal syariah terhadap minat investasi saham di pasar modal syariah (studi pada mahasiswa FEBI IAIN Palu angkatan 2017-2018).

a. Uji Intrumen Penelitian

1) Uji Validitas

Untuk mengetahui mengetahui apakah setiap pertanyaan dalam instrumen itu valid atau tidak, dapat dilihat pada tabel berikut:

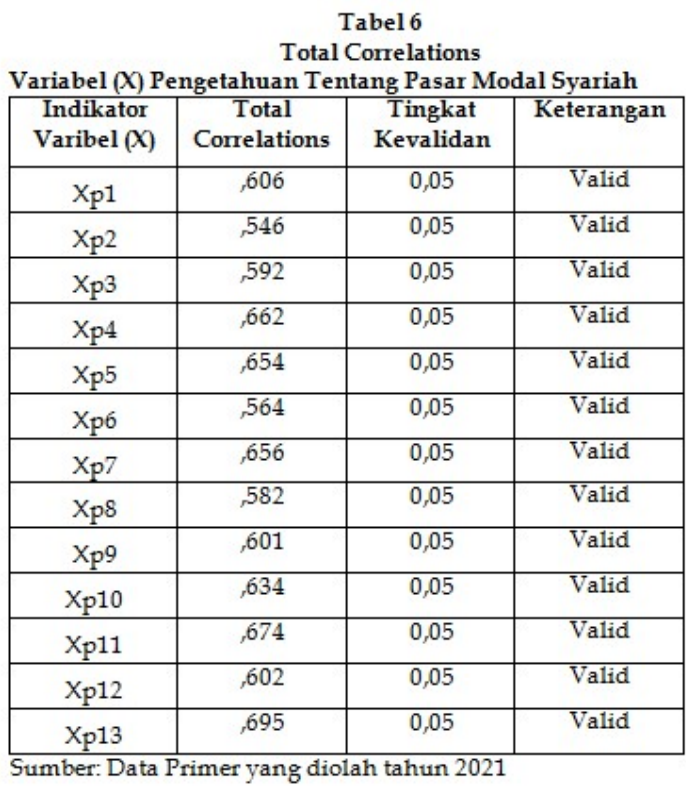

Tabel 7

Total Correlations

Variabel $(Y)$ Minat Investasi Saham

\begin{tabular}{|c|c|c|c|}
\hline $\begin{array}{c}\text { Indikator } \\
\text { Varibel }(\mathbf{X})\end{array}$ & $\begin{array}{c}\text { Total } \\
\text { Correlation }\end{array}$ & $\begin{array}{c}\text { Tingkat } \\
\text { Kevalidan }\end{array}$ & Keterangan \\
\hline Yp1 &, 799 & 0,05 & Valid \\
\hline Yp2 &, 770 & 0,05 & Valid \\
\hline Yp3 &, 876 & 0,05 & Valid \\
\hline Yp4 &, 789 & 0,05 & Valid \\
\hline
\end{tabular}

Sumber: Data Primer yang diolah tahun 2021
Pada tabel 6 dan 7 diatas menunjukkan bahwa semua indikator variabel $X$ dan $Y$ dinyatakan valid. Karena data di katakan valid ketika nilai $r_{\text {hitung }}>\mathrm{r}_{\text {tabel, }}$ sedangkan pada penelitian ini didapatkan nilai $r_{\text {tabel }}$ dengan nilai signifikan 0,05 pada sampel 89 orang ialah 0,207. Jika di bandingkan dengan tiap indikator variabel nilai rhitung melebihi dari nilai $r_{\text {tabel. }}$.

2) Uji Reliabilitas

Suatu kuesioner dikatakan reliable atau handal jika jawaban seseorang terhadap pernyataan adalah konsisten atau stabil.44 Hasil pengukuran realibilitas instrumen menggunakan alat bantu oleh statistik SPSS. Dapat dilihat pada tabel berikut :

Tabel 8

Uji Reliabilitas Pengetahuan Tentang Pasar Modal Syariah Dan Minat Investasi Saham

\begin{tabular}{|l|c|c|l|}
\hline Variabel & $\begin{array}{c}\text { Cronbach's } \\
\text { Alpha }\end{array}$ & $\begin{array}{c}\text { Tingkat } \\
\text { Realibel }\end{array}$ & Keterangan \\
\hline $\begin{array}{l}\text { Pengetahuan tentang } \\
\text { pasar Modal syariah }\end{array}$ &, 858 & 0,60 & Realibel \\
\hline Minatinvestasi saham &, 820 & 0,60 & Realibel \\
\hline
\end{tabular}

Tabel 8 diatas menunjukan nilai Cronbach's Alpha (a) variabel $X$ adalah 0,858 dan variabel $Y$ adalah 0,820 . Kedua variabel tersebut nilia Cronbach's Alpha (a) $\geq 0,60$, maka dinyatakan realibel.

\subsection{Uji Hipotesis}

Uji hipotesis dilakukan dengan Uji T. Uji T dilakukan untuk mengetahui pengaruh antara pengetahuan tentang pasar modal syariah terhadap minat investasi saham di pasar modal syariah, studi pada mahasiswa FEBI IAIN Palu angkatan 2017-2018, maka dilanjutkan Uji $\mathrm{T}$ yang dapat diketahui bahwa Coefficients di atas diperoleh nilai signifikansi sebesar $0,000<0,05$,

44 Imam Ghozali, Aplikasi Analisis Nultivariate Dengan Program IBM SPSS 21, (Cet. VII, Semarang: Badan Penerbit UNDIP, 2013), 47. 
sehingga dapat disimpulkan bahwa variabel Pengetahuan tentang pasar modal syariah $(X)$ berpengaruh terhadap variabel minat investasi saham $(Y)$.

Berdasarkan nilai t diketahui nilai $t_{\text {hitung sebesar } 8,734}>t_{\text {tabel }} 1,663$, sehingga dapat disimpulkan bahwa variabel pengetahuan tentang pasar modal syariah $(X)$ berpengaruh terhadap variabel minat investasi saham $(Y)$. Selanjutnya berdasarkan uji t tersebut, hipotesis dalam penelitian ini yang menyatakan bahwa "Pengaruh pengetahuan tentang pasar modal syariah berpengaruh secara positif dan signifikan terhadap minat investasi saham di pasar modal syariah studi pada mahasiswa FEBI IAIN Palu angkatan 2017-2018", dapat diterima.

\subsection{Pembahasan}

Berdasarkan hasil perhitungan statistik, maka dapat diketahui bahwa variabel pengetahuan tentang pasar modal syariah memiliki nilai thitung sebesar 8,734 > nilai t tabel sebesar 1,663 serta tingkat signifikansi yaitu $0,000<$ 0,05 . Dengan demikian nilai tersebut menunjukan bahwa variabel pengetahuan tentang pasar modal syariah $(X)$ memberikan pengaruh yang signifikan terhadap variabel minat invesatasi saham (Y). Maka, dari pembahasan ini menunjukan bahwa variabel pengetahuan tentang pasar modal syariah mempengaruhi minat investasi saham di pasar modal syariah pada mahasiswa FEBI IAIN Palu angkatan 2017-2018.

Hasil Penelitian ini didukung oleh penelitian sebelumnya yang dilakukan oleh Siti Latifa yang membuktikan bahwa variabel pengetahuan investasi memiliki pengaruh positif dan signifikan terhadap minat investasi di pasar modal syariah, dengan nilai koefisien korelasi sebesar 0,416 dengan nilai signifikan 0,000 .

Pengetahuan tentang pasar modal syariah merupakan suatu pengetahuan atau pemahaman tentang pasar modal syariah, baik memahami produk pasar modal syariah, hukum pasar modal syariah, dan cara bertransaksi di pasar modal syariah.

Penerapan prinsip syariah dipasar modal tentunya bersumberkan pada Al-Qur'an sebagai sumber hukum tertinggi dan Hadits Nabi Muhammad SAW. Selanjutnya, dari kedua sumber hukum tersebut, para ulama melakukan penafsiran yang kemudian disebut ilmu fikih. Salah satu pembahasan dalam ilmu fikih adalah pembahasan tentang muamalah, yaitu hubungan diantara sesama manusia terkait perniagaan. Berdasarkan itulah kegiatan pasar modal syariah dikembangkan dengan basis fiqih muamalah.

Pengetahuan tentang pasar modal syariah merupakan faktor yang sangat penting dalam kegiatan investasi. Karena jika seseorang ingin berinvestasi saham contohnya, maka yang diperlukan harus memahami dimana orang tersebut akan menginvestasikan sahamnya. Ini bertujuan untuk terhindar dari tempat investasi yang ilegal dan investasi yang haram atau dilarang oleh islam. Kesimpulan bahwa variabel pengetahuan tentang pasar modal syariah mempengaruhi minat investasi saham di pasar modal syariah pada mahasiswa FEBI IAIN Palu angkatan 2017-2018.

\section{Kesimpulan}

Penelitian ini bertujuan untuk mengetahui pengaruh pengetahuan tentang pasar modal syariah terhadap minat invesatsi saham di pasar modal 
syariah (studi pada mahasiswa FEBI IAIN Palu angkatan 2017-2018). maka dapat disimpulan bahwa pengujian pada variabel independen yaitu pengetahuan tentang pasar modal syariah terhadap variabel dependen yaitu minat investasi saham, hasilnya menunjukan bahwa variabel pengetahuan tentang pasar modal syariah berpengaruh positif dan signifikan terhadap variabel minat investasi saham. Hal ini dibuktikan dengan hasil analisis data yang menunjukan bahwa nilai thitung sebesar $8,734>$ nilai $t_{\text {tabel }}$ sebesar 1,663 serta tingkat signifikansi yaitu $0,000<0,05$, ini berarti $\mathrm{H}_{\mathrm{a}}$ diterima dan $\mathrm{H}_{\mathrm{o}}$ ditolak.

\section{DAFTAR PUSTAKA}

Yuni Asahari. "Pengaruh Pengetahuan Tentang Bank Syariah Terhadap Minat Menabung di Bank Syariah" Skripsi Tidak Diterbitkan, Jurusan Ekonomi Syariah, IAIN Palu, Palu, 2019

Arikunto, Suharsimi. Prosedur Peneltian, (Suatu Pendekatan Praktik). Jakarta Rineka Cipta, 2010.

Djaali. Psikologi Pendidikan. Cet. I; Jakarta: Bumi Aksara, 2018.

Esi Ermi Alfrita. "Pengaruh Pengetahuan Investasi Terhadap Minat Berinvestasi Mahasiswa Jurusan Ekonomi Syariah Universitas Islam Negeri Sultan Syarif Kasim Riau" Skripsi Tidak diterbitkan, Jurusan Pendidikan Ekonomi, UIN Sultan Syarif Kasim Riau, Pekanbaru, 2019

Firdaus, Muhamma. Sistem Keuangan $\mathcal{E}$ Investasi Syariah Cet. I; Jakarta: Reanaisan, 2005.

Ghozali, Iman. Aplikasi Analisis Nultivariate Dengan Program IBM SPSS 21. Cet. VII, Semarang: Badan Penerbit UNDIP, 2013.
Hamidi, Asep Saipul dan E Baharuddin. Metode Penelitian Kuantitatif Aplikasi dalam Pendidikan. Yogyakarta: Deepulish, 2014.

Hasibuan, Malayu. Manajemen Sumber Daya Manusia Cet.I; Jakarta: PT Bumi Aksara, 2009.

Indrawan, Rilly dan Poppy Yuniawati. "Metodologi Penelitian: Kuantitatif, Kualitatif, dan Campuran Untuk Managemen, Pembangunan, dan Pendidikan, Cet. I; Bandung: PT Refika Aditama, 2014.

Jalil, Abdul, dan Sitti Azizah Hamzah. "Pengaruh Bagi Hasil dan Kebutuhan Modal Terhadap Minat UMKM Mengajukan Pembiayaan Pada Lembaga Keuangan Syariah di Kota Palu" Vol. 2 no. 2 (Tahun 2020). https://jurnaljipsya.org/index.ph $\mathrm{p} /$ jipsya/article/view/31 (Diakses $\underline{25}$ Mei 2021)

Manan, Abdul. Aspek Hukum Dalam Penyelenggaraan Investasi Di Pasar Modal Syariah Indonesia. Cet. II; Jakarta: Kencana 2017.

Malik, Ahmad Dahlan. "Analisa FaktorFaktor Yang Mempengaruhi Minat Masyarakat Berinvestasi Di Pasar Modal Syariah Melalui Bursa Galeri Investasi UISI" Ekonomi Dan Bisnis Islam Vol. 3 No. 1 (Januari-Juli). https://ejournal.unair.ac.id/index.php/JEBI S/article/view/4693 (Diakses 20 September 2020)

Marwatul Fadila, "Pengaruh Citra Merek Terhadap Keputusan Pembelian Motor Yamaha pada Mahasiswa Fakultas Syariah dan Ekonomi Islam IAIN Palu" Skripsi tidak diterbitkan, Jurusan Ekonomi Syariah, IAIN Palu, Palu, 2018

Martono, Nanang. Metode Penelitian Kuantitatif Analisis Isi dan Analisis Data Sekunder, edisi revisi II Cet V; 
Jakarta: PT. Raja Grafindo Persada, 2016.

Noor, Juliansyah. Penelitian Ilmu Manajemen. Cet. I; Jakarta: Kencana, 2013.

Nurdin Nurdin, Winda Nur Azizah, Rusli Rusli, "Pengaruh Pengetahuan, Kemudahan dan Risiko Terhadap Minat Bertransaksi Menggunakan Finansial Technology (Fintech) Pada Mahasiswa Institut Agama Islam Negeri (IAIN) Palu" Vol. 2 no.2 (Tahun 2020). https://jurnaljipsya.org/index.p $\mathrm{hp} /$ iipsya/article/view/32 (Diakses 25 Mei 2021)

Nurdin, N., Musyawarah, I., Nurfitriani, N., \& Jalil, A. (2020). Pengaruh Pelayanan Mobile Banking Terhadap Kepuasan Nasabah (Studi Pada Mahasiswa Perbankan Syariah IAIN Palu) Jurnal Ilmu Perbankan dan Keuangan Syariah, 2(2), 87-104.

Nurdin, N., Pettalongi, S. S., \& Ahsan, M. N. (2019). Implementation of Teaching Quality Assessment System Using Android. Paper presented at the 2019 5th International Conference on Science and Technology (ICST).

Nurdin, N., Pettalongi, S. S., \& Mangasing, M. (2019). Understanding Digital Skill Use from The Technology Continuance Theory (TCT). Paper presented at the 2019 6th International Conference on Information Technology, Computer and Electrical Engineering (ICITACEE).

Nur Kaidah, "Pengaruh Persepsi Mahasiswa Tentang Investasi Terhadap Minat Investasi Saham Di Pasar Modal Syariah", Skripsi Tidak diterbitkan, Jurusan Perbankan
Syariah, UIN Raden Intan Lampung, Lampung, 2018

Oktiana Nur Sari, "Pengaruh Pengetahuan, Keuntungan, Risiko Dan Modal Minimal Terhadap Minat Mahasiswa Untuk Berinvestasi Di Pasar Modal Syariah" Skripsi Tidak Diterbitkan, Jurusan Perbankan Syariah IAIN Surakarta, Surakarta, 2018

Otoritas Jasa Keuangan (OJK), “Pasar Modal Syariah," Situs Resmi OJK. https://www.ojk.go.id/id/kanal/ pasar-modal/Pages/Syariah.aspx (13 Agustus 2020).

Priyanto, Dwi. Analisis Korelasi, Regresi dan Multivariate Dengan SPSS. Cet. 1; Yogyakarta: Gava Media, 2013

Quran

Kemenag,

https:/ / quran.kemenag.go.id/sura L2/278 (01 Februari 2021).

Rodoni, Ahmad. Lembaga Keuangan Syariah. Cet. I; Jakarta: Zikrul Hakim, 2008.

Rizki Chaerul Pajar, "Pengaruh Motivasi Investasi dan Pengetahuan Investasi Terhadap Minat Investasi di Pasar Modal Pada Mahasiswa FE UNY" Skripsi Tidak diterbitkan, jurusan ekonomi, Universitas Negeri Yogyakarta, Yogyakarta, 2017

Sutedi, Adrian Sutedi. Pasar Modal Syariah :Sarana Investasi Keuangan Berdasarkan Prinsip Syariah. Cet. I; Jakarta: Sinar Grafika, 2011.

Sarjono, Haryadi dan Winda Julianita. SPSS VS Lisrel Sebuah Pengantar, Aplikasi Untuk Riset. Jakarta: Salemba Empat, 2011

Sugyono. Metode Penelitian Pendidikan Pendekatan Kuantitatif, Kualitatif dan, $R$ dan D, Cet. 20; Bandung: Alfabeta, 2014.

Siregar, Sofyan. Statistik Deskriptif dalam Penelitian. Cet. I; Jakarta: PT Raja Grapindo Persada, 2010. 
Supardi. Metode Peneltian Ekonomi dan Bisnis. Cet. I; Yogyakarta: UII Pers, 2005.

Slameto. Belajar Dan Faktor-Faktor Yang Mempengaruhinya. Cet. VI; Jakarta: Rineka Cipta, 2015.

Siti Latifah, "Pengaruh Pengetahuan, Modal Minimmal, Dan Motivasi Investasi Terhadap Minat Mahasiswa Untuk Berinvesatsi Di Pasar Modal Syariah" Skripsi Tidak diterbitkan, Jurusan Ekonomi Syariah, IAIN Purworejo, Purworejo, 2019.

Sobur, Alex. Psikologi Umum Dalam Lintasan Sejarah. Cet. I; Bandung: Pustaka Setia, 2010.

Umam, Khaerul. Pasar Modal Syariah $\mathcal{E}$ Praktik Pasar Modal Syariah. Cet. I; Bandung: Pustaka Setia, 2013.

Wibowo, Ari. Pengaruh Pengetahuan Investasi,Kebijakan Modal Minimal Investasi dan Pelatihan Pasar Modal Terhadap Minat Investasi, Jurnal Ilmu Manajemen, vol. 7 no. 1 (Oktober 2019). https://jurnalmahasiswa.unesa.ac. id/index.php/jim/article/view/25 386 (Diakses 27 September 2020).

Yuliana, Susilowati, "Faktor- Faktor Yang Mempengaruhi Minat Mahasiswa Akuntansi Syariah Untuk Berinvestasi Di Pasar Modal Syariah" Skripsi Tidak diterbitkan, Jurusan Akuntansi Syariah, IAIN Surakarta, Surakarta, 2017. 